Kocaeli Journal of Science and Engineering

\title{
Experimental Study of the Performance of a Li-Ion Battery Cell in a Highway Driving Cycle
}

\author{
Ali AMINI ${ }^{1, *}$ (ID), Baybars ÖZELCi ${ }^{2}$ (D), Tanılay ÖZDEMIR ${ }^{3}$ (D), Özgür EKİCi ${ }^{4}$ (D), S. Çağlar BAŞLAMIŞLI ${ }^{5}$ (DD), \\ Murat KÖKSAL ${ }^{6}$ (D)
}

${ }^{I}$ Department of Mechanical Engineering, Hacettepe University, Ankara, 06800, Turkey, ORCID: 0000-0002-4668-5258

${ }^{2}$ Department of Mechanical Engineering, Hacettepe University, Ankara, 06800, Turkey, ORCID: 0000-0003-2649-8612

${ }^{3}$ Department of Mechanical Engineering, Hacettepe University, Ankara, 06800, Turkey, ORCID: 0000-0003-1692-9781

${ }^{4}$ Department of Mechanical Engineering, Hacettepe University, Ankara, 06800, Turkey, ORCID: 0000-0002-1370-7190

${ }^{5}$ Department of Mechanical Engineering, Hacettepe University, Ankara, 06800, Turkey, ORCID: 0000-0002-7476-2257

${ }^{6}$ Department of Mechanical Engineering, Hacettepe University, Ankara, 06800, Turkey, ORCID: 0000-0003-1509-2246

Article Info

Research paper

Received : : December 31, 2019

Accepted : June 30, 2020

Keywords

Driving Cycle

Electric Vehicle

Li-Ion Battery

Thermal Behavior

\begin{abstract}
Li-ion batteries, as a secondary battery type, are currently the most viable option for powering hybrid/electric vehicles. They have considerable advantages such as high specific energy and power, no memory effect, long cycling life, low maintenance requirement, and low self-discharge rate. However, their thermal performance can easily deteriorate at extreme ambient temperatures. Therefore, in this study, thermal and electrical behaviors of Li-ion batteries were investigated under various operating temperatures using a driving cycle that represents a highway driving condition. A battery testing system was used to determine the performance of Li-ion batteries under simulated loads. The results show that the measured temperature profiles, in broad strokes, follow the current profile. Because of the thermal capacitance of the battery, the changes in temperature variations are observed to be the smoothened out version of the current profile. Moreover, the results show that the extreme ambient temperatures have adverse effects on thermal performance of $\mathrm{Li}$-ion batteries. The volumetric energy density and the capacity of the cell significantly decrease at cold ambient temperatures, especially for the sub-zero temperature applications possibly due to weak ionic conductivity within the cell. On the other hand, the difference between the ambient temperature and the surface of the cell becomes more pronounced as the ambient temperature decreases.
\end{abstract}

\section{Introduction}

Li-ion batteries have been widely using in electric vehicles and most of the portable electronic devices since they offer higher energy density, higher cycling life, and low self-discharge rate compared to the other power sources [1]. There are various studies related to improving the energy density and capacity of the Li-ion batteries in order to increase the acceleration rate and the driving range of the electric vehicles. However, as the energy requirement from the $\mathrm{Li}$-ion batteries continues to develop, the safety risk increases as well.

\footnotetext{
* Corresponding Author: ali82amini@gmail.com
}

This article is an extended version of the paper presented at the $22 \mathrm{nd}$ Congress on Thermal Science and Technology.
Safety concerns on Li-ion batteries are mostly related to the thermal behavior of the battery. Pesaran et al. stated that the operating temperature range of Li-ion batteries should be kept between $15-35^{\circ} \mathrm{C}$ since both high and low temperatures have adverse effects on Li-ion batteries thermal performance [2]. The increment of operating temperature can produce severe degradation problems and reduce battery lifespan [2]. Using of battery cells in pack design requires more attention to temperature distribution. Thermal management in this kind of design is utilized by cooling systems. Poor conductivity of cell stack to the cooling plate and asymmetric design of battery cells can affect on the performance of battery cells significantly [3].

Motloch et al. indicated that within the temperature range of $30-40^{\circ} \mathrm{C}$, each increment of working temperature 
caused a reduction in battery life approximately two months [4].

Elevated operating temperatures can cause a capacity fade of the Li-ion cell as the cell is cycled. Ramadass et al. cycled a Sony $18650 \mathrm{Li}$-ion cell both at room temperature and at $45^{\circ} \mathrm{C}$ and found the capacity of the cell at $45^{\circ} \mathrm{C}$ decreased $6 \%$ more after 800 cycles [5]. As an extreme condition, if the temperature within the cell reaches a point in which the exothermic side reactions can be triggered, these reactions exponentially increase the heat generation within the cell and may lead to a possible thermal runaway condition [6].

Li-ion batteries are preferred due to their high volumetric energy density values, which provide the user to manage the working area effectively. However, the volumetric energy density of the cell significantly decreases at cold ambient temperatures, particularly for the subzero temperature applications. Nagasubramanian examined the energy density of a 18650 Panasonic Li-ion cell in a temperature range between $-40^{\circ} \mathrm{C}$. and $25^{\circ} \mathrm{C}$. He found that the volumetric energy density of the cell was reduced to $95 \%$ at $-40^{\circ} \mathrm{C}$ compared to that at room temperature [7].

Jaguemont et al. performed an experiment at $50 \mathrm{~A}$ discharging current and demonstrated that the energy that could be obtained from a 100-Ah LiFeMnPO4 Li-ion cell reduced from $302 \mathrm{Wh}$ to $183 \mathrm{Wh}$ as the ambient temperature decreased from the room temperature to the $25^{\circ} \mathrm{C}$ [8]. Huo et al. investigated the thermal behavior of a Li-ion cell at various ambient temperatures during a galvanostatic discharging process and observed that the temperature gradient at the surface center of the cell became sharper as the temperature decreased [1].

There are few studies that investigated the battery thermal behavior under driving cycle loads. Tourani et al. composed a combination of ECE15 and EUDC driving cycles to test their battery model that was working under normal ambient conditions [9]. They estimated the temperature variation of battery cell and verified that by experimental data. Panchal et al. investigated electrical and thermal behavior of lithium-ion battery package of vehicle travelling on both highway and city driving cycle [10]. The ambient temperature was between $2-17^{\circ} \mathrm{C}$ in this comprehensive study [10].

To the best of authors' knowledge, there is no study that addresses the thermal behavior of battery cell under driving cycle load working in different ambient conditions.

In this experimental study, first, a battery testing system was used to determine the surface temperature of the cell at given current inputs during charging or discharging processes of the driving cycle. Then, FTPHighway (Federal Test Procedure) driving cycle was simulated by applying the corresponding current values to the Li-ion cell in order to investigate the thermal behavior of the battery under various operating conditions.

\section{Materials and Methods}

\subsection{Experimental Setup and Procedure}

An experimental setup was established in order to investigate the thermal behavior of the Panasonic NCR18650B cylindrical Li-ion battery cells under driving cycle loads, which is shown in Figure 1. A battery test stand was designed in a way to test 4 battery cells simultaneously. Figure 1(a) shows the battery-testing device (Maccor 4300) which was used to determine the quality and performance of Li-ion batteries by applying simulated loads under computer control. The surface temperature of the cell was measured by T-type thermocouples as shown in Figure 1(b). According to previous studies, the maximum temperature difference between surface and center of battery cells during charge/discharge process are not significant. Also, a single temperature measurement point can provide adequate data regarding battery thermal behavior [11].

The thermocouples were connected to the NI (National Instrument) USB 6341 data acquisition device. Special design of clamp was used to minimize the contact resistance between battery surface and thermocouple tip.

First of all, a set of galvanostatic tests were done in different charge and discharge current values. Testing time was lasted 30, 60 and 90 minutes, depending on $C$ rate values. The C-rate is a measure of the rate at which a battery is being charged or discharged.

In the second step, a specific current profile was generated by the vehicle model and was loaded to the battery-testing device. Every driving cycle test for a single battery was composed of 5 cycles and lasted 64 minutes.

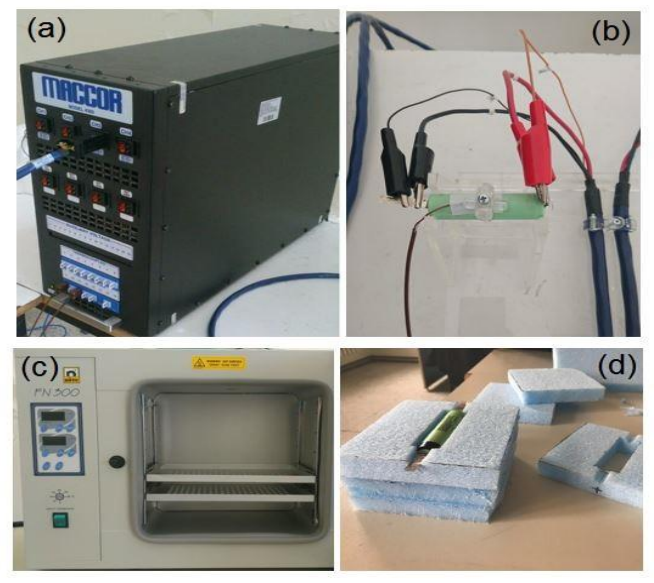

Figure 1. Experimental set-up (a) battery test device (b) battery cell test stand (c) oven (d) insulation around a battery. 
Experiments were done for various operating temperatures: $-20,0,20,40$, and $60{ }^{\circ} \mathrm{C}$. A refrigerator and a natural convection oven as shown in Figure 1(c) were used to provide the required ambient temperatures during the experiments. Moreover, a nearly adiabatic operating condition was simulated using a foam insulation around the cell as shown in Figure 1(d). All tests were carried out simultaneously for 4 different battery cells to detect and prevent possible installation and measurement errors.

\subsection{Modelling}

\subsubsection{Vehicle Dynamic Model}

An electric vehicle model was constructed in MATLAB/Simulink environment. In this model, power request of vehicle was calculated according to tractive force, inertial, rolling and air resistance forces. Detailed explanation about the resistance forces calculation can be found in Boyalı et al. [12]. Efficiency map of electric motor was assumed as a function of its torque and angular speed. Battery modeling was also implemented using an equivalent circuit diagram, where battery internal resistance is a function of state of charge (SoC). The electrical current drawn from the battery during charging and discharging situations was calculated with the following equations [12];

$I_{\text {chg }}=\frac{-\mathrm{V}_{\text {ocv }}+\sqrt{\mathrm{V}_{\text {ocv }}{ }^{2}+4 \mathrm{R}_{\mathrm{i}} \mathrm{P}_{\text {chg }}(\mathrm{t})}}{2 \mathrm{R}_{\mathrm{i}}}$

$I_{\text {dis }}=\frac{V_{\text {ocv }}-\sqrt{V_{\text {ocv }}{ }^{2}-4 R_{i} P_{\text {dis }}(t)}}{2 R_{i}}$

In Eq. (1) and Eq. (2), $P_{\text {chg }}(t), P_{\text {dis }}(t)$ are the charge loads during charging and discharging at the battery terminal, $\mathrm{V}_{\text {oc }}$, open circuit voltage and $\mathrm{R}_{\mathrm{i}}$ are internal resistances of the battery.

Vehicle dynamic model is summarized in Figure 2 and Figure 3.

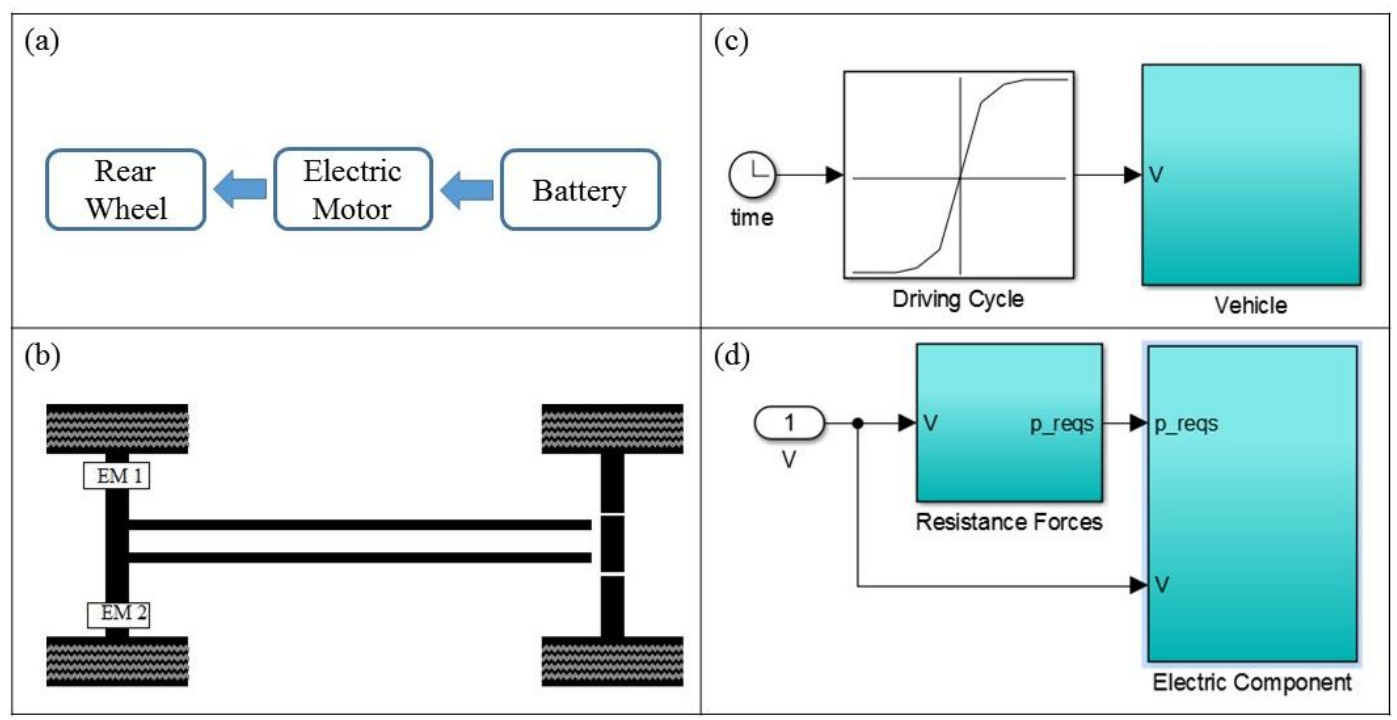

Figure 2. Vehicle architecture (a) energy flow (b) vehicle structure (c) reverse vehicle model (d) vehicle dynamic blocks.

Figure 2(a) illustrates the energy flow in vehicle model. The position of electric motors and their connection with rear wheels are shown in Figure 2(b). Figure 2(c) and Figure 2(d) show the reverse vehicle model. Over the time steps, driving cycle box sends velocity values to the vehicle model and the desired torque and speed values are calculated for electric motor to proceed to the next step (Figure 3). According to resistance force values, it is possible to calculate the time variant velocity and requested torque of vehicle. By knowing the speed reduction ratio, the speed and torque values of electric motor are calculated. By considering the efficiency of electric motor, it is possible to calculate the battery electric power. In battery sub model, equivalent circuit diagram was composed to find the battery voltage and current values.

\subsubsection{Vehicle Parameters}

The specifications of a prototype electric vehicle model are given in Table 1. The parameters were selected according to the Hybrid/Electric prototype vehicle that was 
designed in Hacettepe University Senstech Laboratory. It consists of two hub electric motors in front wheels. Also, the battery package was selected according to current and voltage limits of Maccor testing system.

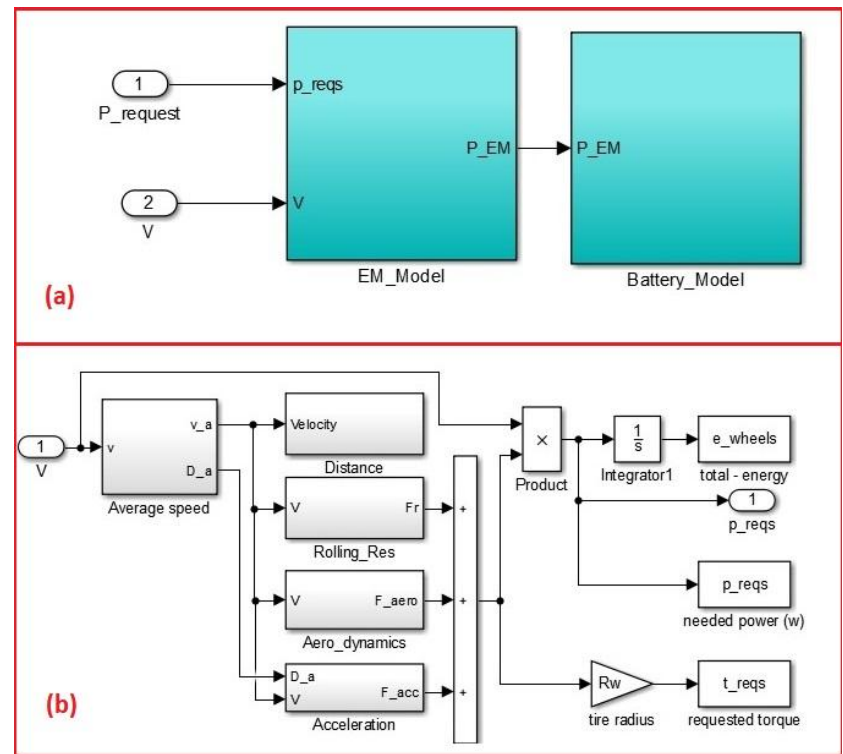

Figure 3. Detailed view of vehicle model (a) electric motor and battery (b) resistance forces.

Table 1. Prototype electric vehicle parameters.

\begin{tabular}{|c|c|c|}
\hline Element & Parameter & Value \\
\hline \multirow[t]{5}{*}{ Vehicle } & Mass & $400[\mathrm{~kg}]$ \\
\hline & $\begin{array}{l}\text { Air Resistance } \\
\text { Coefficient }\end{array}$ & 0.5 \\
\hline & Air Density & $1.24\left[\mathrm{~kg} / \mathrm{m}^{3}\right]$ \\
\hline & Frontal Area & $2\left[\mathrm{~m}^{2}\right]$ \\
\hline & Wheel Radius & $0.2925[\mathrm{~m}]$ \\
\hline \multirow[t]{3}{*}{ Gearbox } & Gear Ratio & 1 \\
\hline & Final Drive Ratio & 1 \\
\hline & $\begin{array}{l}\text { Transmission } \\
\text { Efficiency }\end{array}$ & 0.99 \\
\hline \multirow{3}{*}{$\begin{array}{l}\text { Electric } \\
\text { Motor }\end{array}$} & Maximum Torque & $2 \times 270[\mathrm{Nm}]$ \\
\hline & Maximum Power & $2 \times 13.7[\mathrm{~kW}]$ \\
\hline & $\begin{array}{l}\text { Maximum Angular } \\
\text { Velocity }\end{array}$ & $570[\mathrm{RPM}]$ \\
\hline \multirow{3}{*}{$\begin{array}{l}\text { Battery } \\
\text { Package } \\
(24 \mathrm{~s} \text { x 35p) }\end{array}$} & Capacity & $114[\mathrm{Ah}]$ \\
\hline & Open Circuit Voltage & $100[\mathrm{~V}]$ \\
\hline & Maximum Current & $175[\mathrm{~A}]$ \\
\hline \multirow{3}{*}{$\begin{array}{l}\text { Battery } \\
\text { Cell }\end{array}$} & Capacity & $3.25[\mathrm{Ah}]$ \\
\hline & Open Circuit Voltage & $4.2[\mathrm{~V}]$ \\
\hline & Maximum Current & $5[\mathrm{~A}]$ \\
\hline
\end{tabular}

\subsubsection{Driving Cycle}

In order to examine the battery cell reaction for different operating conditions, 'FTP-Highway' driving cycle was used in EPA [13]. Vehicle speed and traveled distance in this condition are shown in Figure 4. According to simulation results, battery cell parameters variation is shown in Figure 5. The current profile of the battery cell was used as input data in experimental studies.
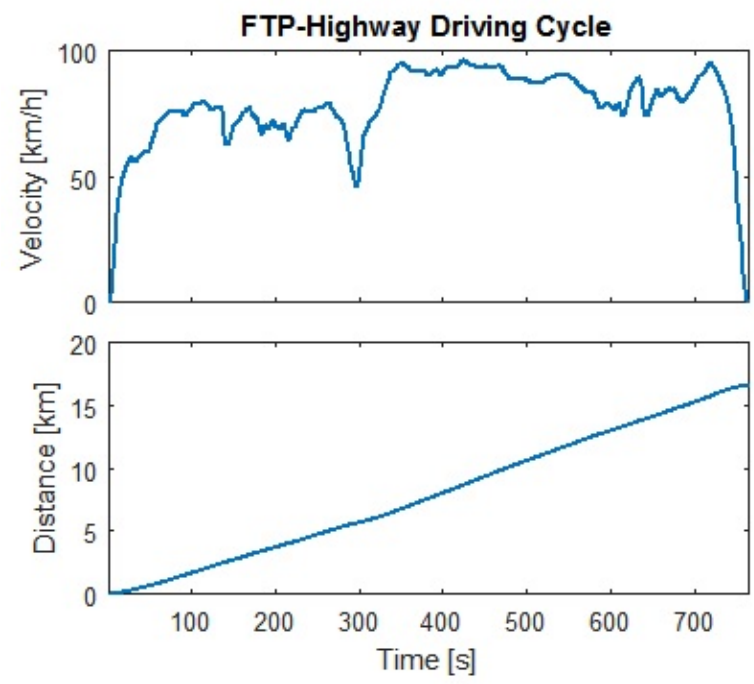

Figure 4. Variation of the velocity and distance with time in the driving cycle.

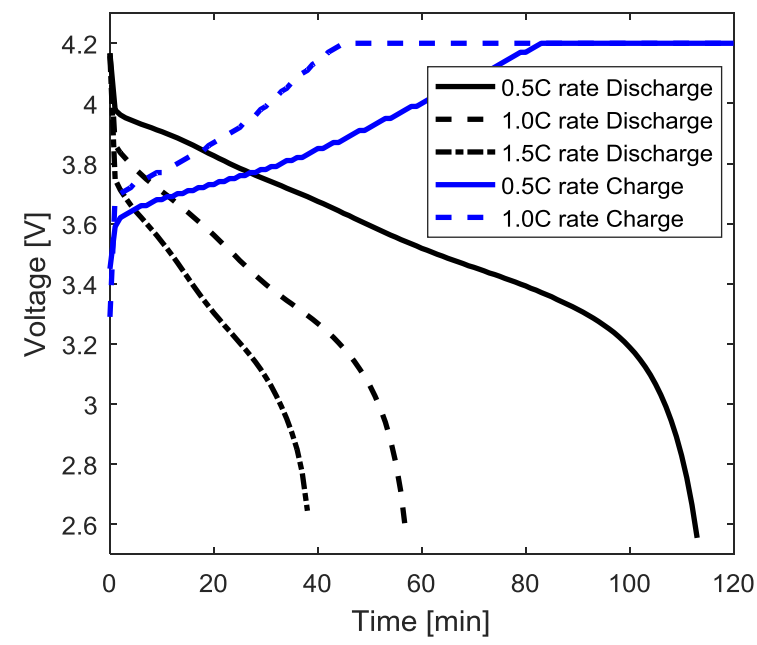

Figure 5. Voltage variation for different galvanostatic discharge/charge applications.

\section{Results and Discussion}

\subsection{Galvanostatic Charge/Discharge}

Before starting the planned tests within the scope of the study, various test measurements were performed in order to test the accuracy of measurement equipment. In the first step, voltage-time values for 18650 Li-Ion batteries in different galvanostatic (constant current) discharge/charge modes were measured and presented in Figure 6. Discharge tests were done at typical values of $0.5 \mathrm{C}, 1.0 \mathrm{C}$, and $1.5 \mathrm{C}$ rates. As it is known, the $1.0 \mathrm{C}$ discharge rate refers to the constant current for discharging a full capacity of a battery in one hour. For Panasonic NCR18650B battery cell, this constant current value is 
3.25 A. Since the maximum current value allowed by the Maccor testing system in our laboratory is $5.0 \mathrm{~A}$, the upper current value for the discharge tests was limited to $1.5 \mathrm{C}$ rate. The termination of discharge test was performed automatically when the minimum voltage was reached to $2.5 \mathrm{~V}$, which is the permitted voltage that is recommended by the battery manufacturer. Charge tests were done at typical values of $0.5 \mathrm{C}, 1.0 \mathrm{C}$ rates $(0.5 \mathrm{C}$ rate is the ideal current that is recommended by the battery manufacturer). As it can be seen in Figure 5, the termination of the charge process was determined by a voltage limit similar to discharge process. As seen in Figure 5, except the beginning and ending time of charge/discharge processes, battery cell voltage has a linear dependency with time. One of the main differences that can be observed in charge and discharge applications is the progression of the process approaching the end time. Voltage is limited to $4.2 \mathrm{~V}$ towards the end of the charging process. However, in discharging, voltage variation is sharper at the end of the process. As a result, the values presented in Figure 5 show the expected trends and the nominal values presented in the technical specifications document of the Panasonic NCR18650B battery cell. On the other hand, the standard charging procedure starts with the constant current value, but when the specified voltage value is reached, the process continues with decreasing current values. This standard procedure is applied to extend the life of the battery. In the constant voltage region of the charging process, depending on decreasing current values, the natural convection cooling dominates the decreasing heat generation and the surface temperature is decreased as presented in Figure 6.

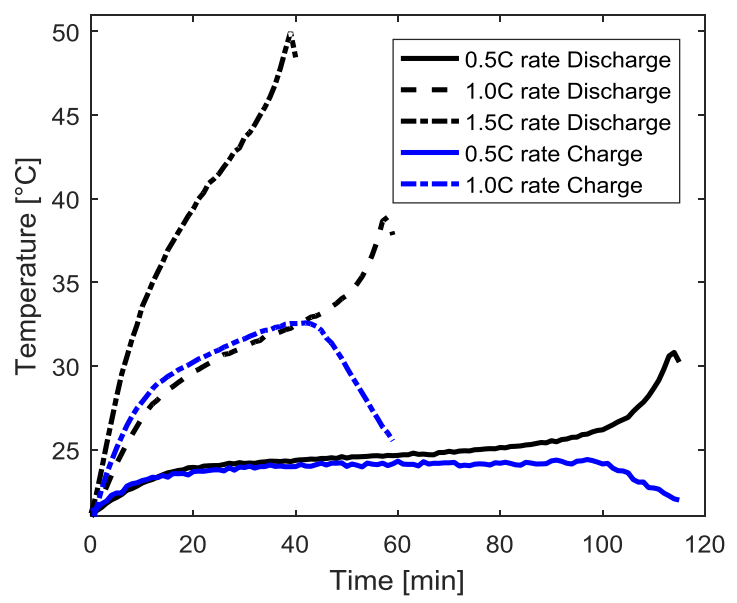

Figure 6. Surface temperature variation for different galvanostatic discharge/charge rates.

\subsection{Battery Cell Behavior in a Driving Cycle}

In order to tune the battery sub-model in vehicle model, galvanostatic discharge/charge tests results were used. Battery sub-model internal resistance and open circuit voltage (OCV) were adjusted in a way to cover experimental voltage-time values.

After this adjustment, vehicle model was run in FTPHighway driving cycle. Figure 7 shows the variation of the battery cell parameters in this driving cycle. According to the results, the battery current was bounded in permitted values and battery SoC (state of charge) was decreased about $15 \%$. SoC value at the end of one cycle shows that this vehicle with specified parameters can repeat the driving cycle 5 times until depleting the battery cell capacity simultaneously.

Figure 8 shows the current-time values that were obtained by repeating the driving cycle 5 times. This time dependent current profile was chosen as input data for battery cell tests. The battery testing device was programmed to impose this profile on battery cells while their surface temperature was measured simultaneously.
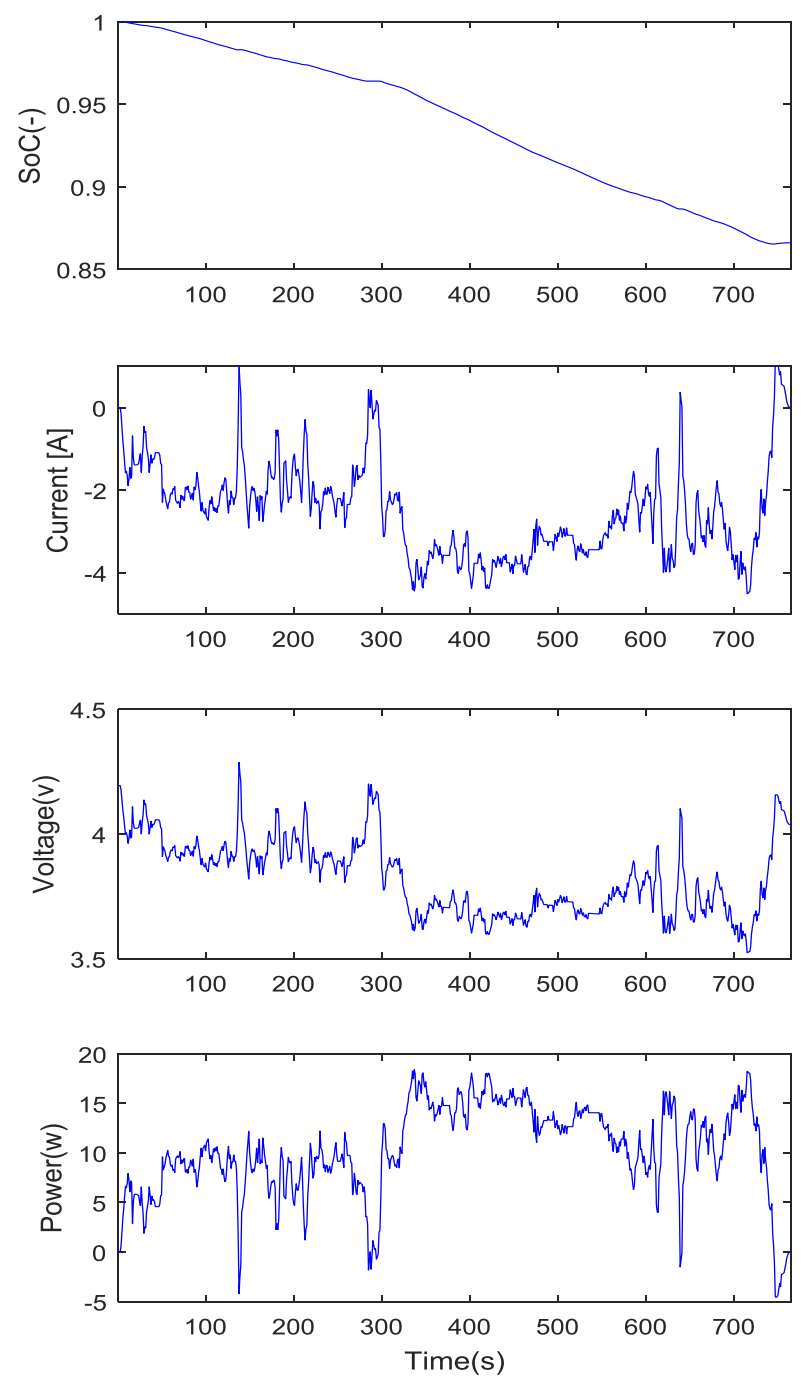

Figure 7. Battery cell parameters variation in FTPhighway driving cycle. 


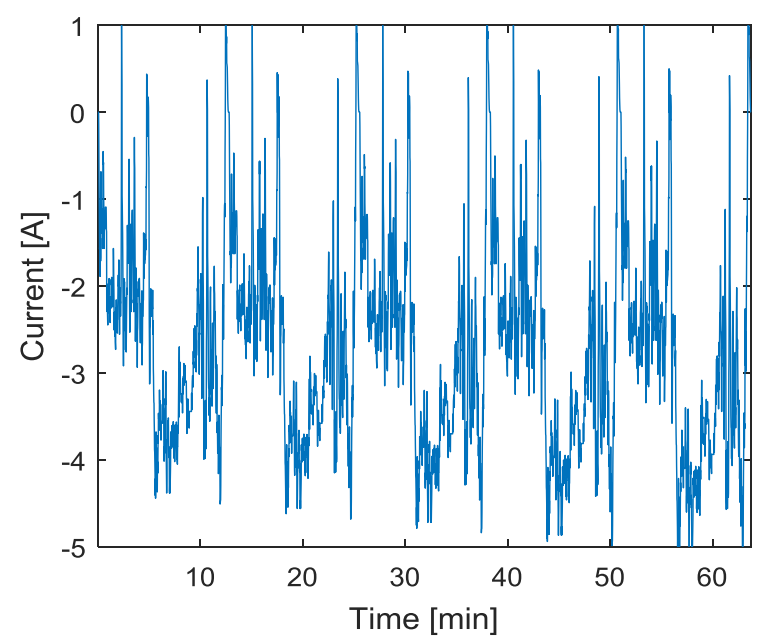

Figure 8. Current-time values implemented on battery cells.

A summary of ambient conditions is listed in Table 2 . D1 case represents the room condition where the battery is exposed to ambient air. D2 and D3 represent the conditions with temperatures below and above the room temperature, respectively. In addition, D4 represents the experiments at which the battery cell was covered by insulation to provide a nearly adiabatic operating condition.

Table 2. Case studies conducted in this study.

\begin{tabular}{|l|l|l|}
\hline $\begin{array}{l}\text { Case } \\
\text { Study }\end{array}$ & $\begin{array}{l}\text { Ambient } \\
\text { Temperature }\left({ }^{\circ} \mathrm{C}\right)\end{array}$ & Used Device \\
\hline D1 & 20 & Room \\
\hline D2 & $-20,0$ & Refrigerator \\
\hline D3 & 40,60 & Oven \\
\hline D4 & $-20,20$ & Insulation \\
\hline
\end{tabular}

\subsection{Battery Cell Thermal Behavior under Different Ambient Conditions}

Figure 9 presents the battery surface and ambient temperature in $\mathrm{D} 3\left(40^{\circ} \mathrm{C}\right)$. Temperature variation shows an oscillatory behavior depending on the current input. The amplitude of these oscillations, which are characterized by increasing and decreasing battery surface temperature values, is approximately $2^{\circ} \mathrm{C}$ for the FTP-Highway driving cycle. In order to evaluate the case study results and the effects of applied driving cycle on the thermal behavior of the battery cell, the difference between the battery surface temperature and ambient temperature is shown in Figure 10(a). As can be seen from the figure, the temperature difference i.e., temperature rise of the battery, varies inversely with the ambient temperature. This means that in a cold environment, the battery cell tries to meet the same electrical requirements at the expense of generating more heat that is leading to higher surface temperature relative to the ambient.

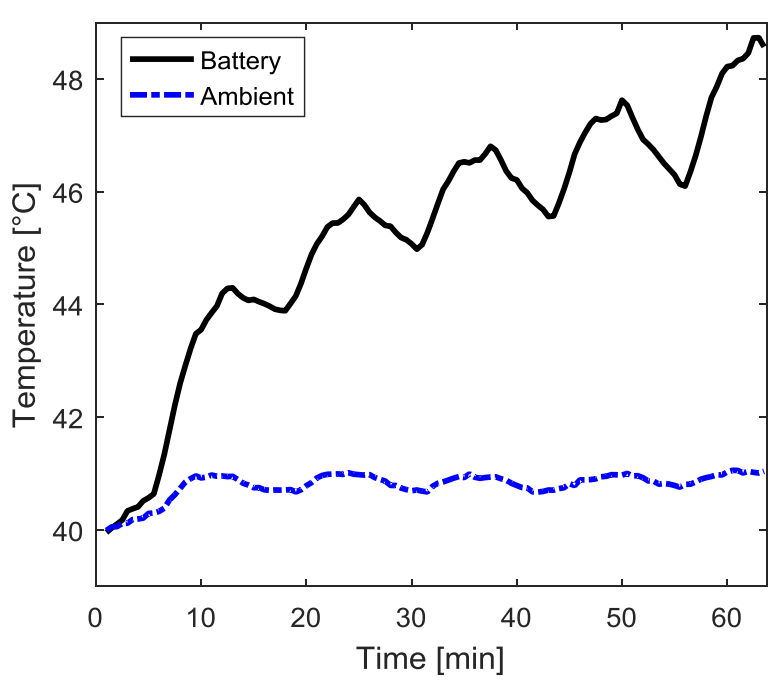

Figure 9. Battery surface temperature in FTPHighway driving cycle (D3).

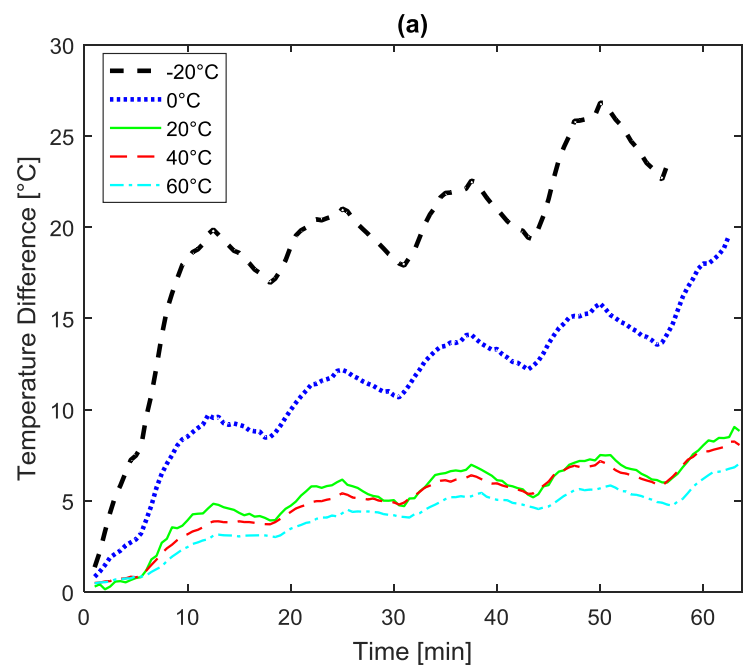

(b)

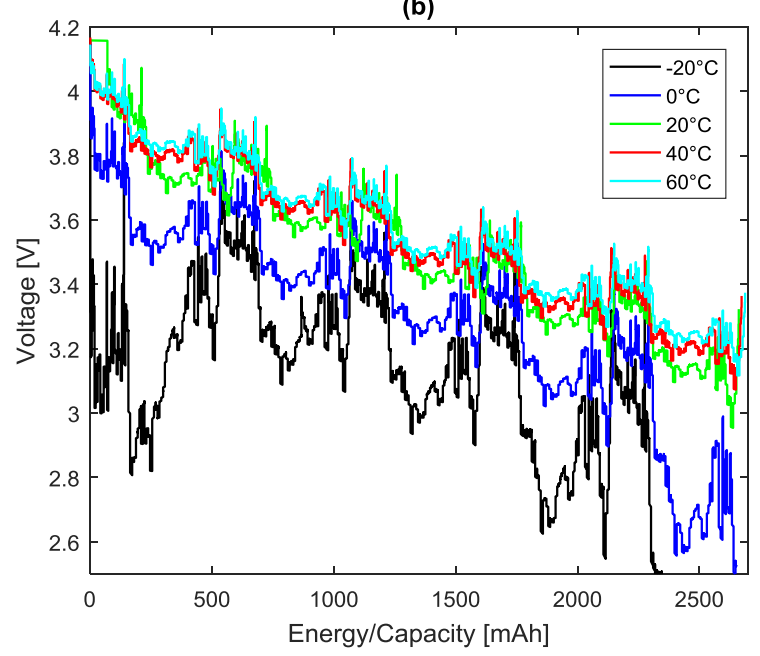

Figure 10. Battery behavior in FTP-highway driving cycle (D1, D2, D3) (a) surface temperature differences (b) voltage. 
This is believed to be the result of increased internal resistance of the battery at low temperatures. The experimental results at -20 and $0^{\circ} \mathrm{C}$ operating temperatures show that there are $20^{\circ} \mathrm{C}$ and $10^{\circ} \mathrm{C}$ temperature differences after the first driving cycle respectively. However, the corresponding temperature rise is less than $5^{\circ} \mathrm{C}$ for the other operating conditions.

According to the variation of temperature data in Figure $10(\mathrm{a})$, the experiment with $-20^{\circ} \mathrm{C}$ ambient temperature has been cut on $56^{\text {th }}$ minute because the battery cell voltage has dropped below $2.5 \mathrm{~V}$. The same cutoff limit has been reached for $0^{\circ} \mathrm{C}$ experiment at $63^{\text {rd }}$ minute. On the other hand, all the other cases were able to complete the full five-cycle duration of 64 minutes without premature ending. Figure 10(b) presents the variation of battery capacity during experiments. The experiment with $20^{\circ} \mathrm{C}$ ambient temperature showed the lowest capacity (2345 mAh).

Among the battery thermal behavior tests, the highest temperature difference was observed in D4 case study. Figure 11 shows the battery surface temperature difference obtained under insulation. According to the results, a temperature difference of $46^{\circ} \mathrm{C}$ was experienced in D4 ($20^{\circ} \mathrm{C}$ ) case, which is significantly higher than $30^{\circ} \mathrm{C}$ temperature difference obtained in $\mathrm{D} 2\left(-20^{\circ} \mathrm{C}\right)$. Therefore, the insulation magnifies the temperature difference as expected. It is also interesting to note that, early cutoff experienced with $-20^{\circ} \mathrm{C}$ ambient temperature does not occur under the adiabatic-like conditions due to a large increase in the cell temperature as a result of insulation.

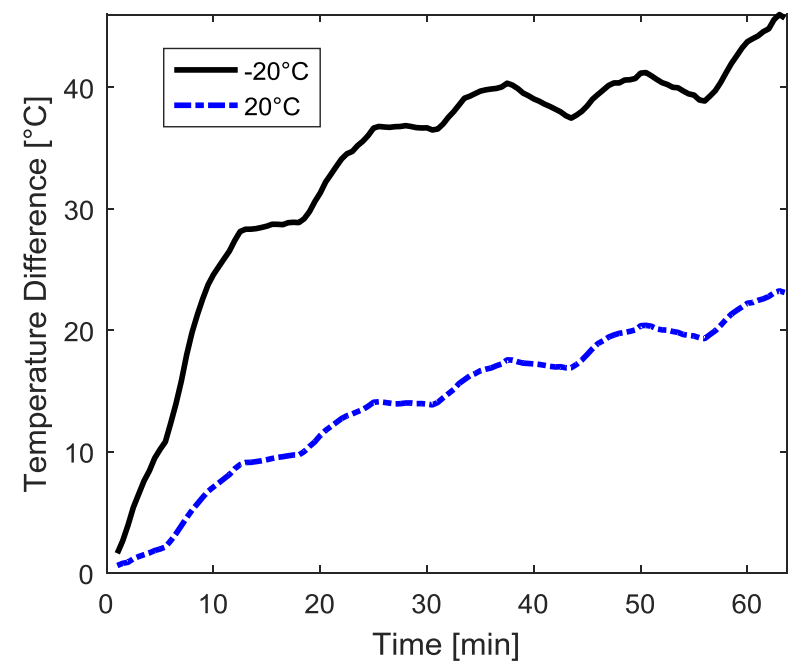

Figure 11. Battery surface temperature difference in FTP-highway driving cycle (D4).

\section{Conclusions}

In this paper, the thermal behavior of a Li-ion cell was examined under the FTP driving cycle at various operating temperatures. The results show that the operating temperature has significant effects on the thermal performance of Li-ion batteries. It was found that the cold operating temperatures caused a significant increase in heat generation and surface temperature due to increasing internal resistance value of the cell.

Cold ambient conditions also lead to a severe decrement of the volumetric energy density and the capacity of the cell possibly due to weak ionic conductivity within the cell. Besides, it can be concluded from the given results that the difference between battery cell surface and ambient temperature is more pronounced as the ambient temperature decreases.

\section{Acknowledgements}

The authors would like to thank Scientific and Technological Research Council of Turkey (TÜBİTAK) for their support in the funding of this study (project no. 216M048).

\section{References}

[1] Huo W., He H., Sun F., 2015. Electrochemicalthermal Modeling for a Ternary Lithium Ion Battery During Discharging and Driving Cycle Testing. Royal Society of Chemistry Advancement, 5, pp. 57599-57607.

[2] Pesaran A. A., 2002. Battery Thermal Models for Hybrid Vehicle Simulations. Journal of Power Sources, 110, pp. 377-382.

[3] Chung Y., Kim M. S., 2019. Thermal Analysis and Pack Level Design of Battery Thermal Management System with Liquid Cooling for Electric Vehicles. Energy Conversion and Management, 196, pp. 105116.

[4] Motloch C., Christophersen J., Belt J., Wright R., 2002. High-power Battery Testing Procedures and Analytical Methodologies for HEV's. SAE, 797-802 doi: 10.4271/2002-01-1950.

[5] Ramadas P., Haran B., White R., Popov B. N., 2002. Capacity Fade of Sony 18650 Cells Cycled at Elevated Temperatures: Part I Cycling Performance. Journal of Power Sources, 112, pp. 606-613.

[6] Bandhauer T. M., Garimella S., Fuller T. F., 2011. A Critical Review of Thermal Issues in Li-Ion Batteries. Journal of the Electrochemical Society, 158, pp. 1-25.

[7] Nagasubramanian G., 2001. Electrical Characteristics of $18650 \mathrm{Li}$-ion Cells at Low Temperatures. Journal of Applied Electrochemistry, 31, pp. 99-104. 
[8] Jaguemont J., Boulon L., Dube Y., Poudrier D., 2014. Low Temperature Discharge Cycle Tests for a Li-Ion cell. Proceeding of IEEE Vehicle Power and Propulsion Conference, Coimbra, Portugal, 27-30 October, pp. 1-6.

[9] Tourani A., White P., Ivey P., 2014. Analysis of Electric and Thermal Behavior of Lithium-ion Cells in Realistic Driving Cycles. Journal of Power Sources, 268, pp. 301-314.

[10] Panchal S., Mathew M., Dincer I., Agelin-Chaab M., Fraser R., Fowler M., 2018. Thermal and Electrical Performance Assessments of Lithium-ion Battery Modules for an Electric Vehicle under Actual Drive Cycles. Electric Power Systems Research, 163, pp. 18-27.

[11] Mastali M., Foreman E., Modjtehedi A., Samadani E., Amirfazli A., Fraser R. A., Fraser R. A., Fowler M., Farhad S., 2018. Electrochemical-thermal Modeling and Experimental Validation of Commercial Graphite/LiFePO4 Pouch Lithium-ion Batteries, International Journal of Thermal Sciences, 129, pp. 218-230.

[12] Boyalı A., Güvenç L., 2010. Modeling and Rule Based Control of Hybrid Electric Vehicles. İTÜ Journal/D engineering, 9, pp. 83-94.

[13] EPA, 2019. Vehicle and Fuel Emissions Testing. United States Environmental Protection Agency, https://www.epa.gov/vehicle-and-fuel-emissionstesting/vehicle-testing-regulations.

(Access Date: 01.01.2018). 